\title{
Management Education in Action on Transforming Intellectual Capital Toward Social Entrepreneurship
}

\author{
Palin Phoocharoon \\ National Institute of Development Administration \\ NIDA Business School, Bangkok, Thailand
}

\begin{abstract}
Although, evidence shows that new innovation of information communication technology represents the most advance and active which has strong influence on business activities, understanding antecedents of the process of how organization reconfigure resources in order to address social problem and achieve social change have been largely ignored. Recognizing that why some organizations engage in social comprehensive innovative behavior and others do not has drawn an attention on intellectual capital toward management education and social learning process. Particularly, the role of one that be able to recognize the power and the value of intellectual capital is determined. It is because the recent "social problems" which considering as "crisis of business management", lead us on both recognize and renewal current business cognitive and platform. The study proposed a new dimension of intellectual capital through new management education platform. Determining on shifting business purpose from economic value to social constructive value need to embed in our young leaders before it too late.
\end{abstract}

Key words: Management education, intellectual capital, social entrepreneurship, innovation, young leaders, economic value

\section{INTRODUCTION}

In its essence, enhancing organizational capability to coup with a disruptive condition is a big challenge for the firms. Therefore, most of the firms intend to survive by ignoring how much resources will be utilized in order to foster innovation for its own advantage. Over the past decade, organizational researchers have begun to develop increasingly comprehensive models of creating competitive advantage even it simply means that another one, even its own society will be disadvantage. Therefore, scholars of the theory of the firm also have begun to emphasize the causes, consequence and purpose of what have been determined competitive rather than focus on sources and conditions of advantage of business matters (Nahapiet and Ghoshal, 1998). It is because the recent global financial and economic crisis which on considered a "crisis of management" and that "management education" appears to be a significance part (Mintzberg, 2009). Thus, the intense pressure rest on business school which is one of social capital outcome, to answer whether those evidences results from management education. Since, most business programs still have placed emphasis on "maximizing profit" rather than "sustainable" through green innovation that concern both economic and social value simultaneously. All demand for radical and rapid reforms in the management education to embed new intellectual capital to young managers of the future (Gosling and Mintzberg, 2006; O'Toole, 2009).

The first purpose of the study was to integrate the current conceptualizations of social economy as they pertain to sustainable growth through social entrepreneurship. The main contribution of the current investigation to social learning on education is to provide a new conceptual of management education in action. Social entrepreneurship has been attracting widely interest over the past decade. The concept was accepted and viewed as a potential solution to social exclusion and as a means of developing sustainable communities. The second purpose of this study was to model intellectual capital effects on a designed framework of social learning and organizational learning system and their efforts to address a social problem or effect social change (Tracey et al., 2005) with other processes known to be determinants of sustainable growth.

The third purpose of this study was to integrate research on social identity theory and self-efficacy with that on social capital, organizational capital and human capital which manifest itself as intellectual capital (Nahapiet and Ghoshal, 1998; Schultz, 1971). Research has explored the origin and progress of social capital which centrally concerned with the significance of relationship as a resource for social action (Coleman, 1990). Embedded 
social identity to social entrepreneurship education is becoming essentially prevalent in business school, highlighting the need for effective program. Drawing on social identity theory and research on self-efficacy on facilitating young leader develop identities as social entrepreneurs and gain confidence in their innovative ability that effect positive social change is presented. In this study, social capital was used to extend to design the comprehensive model of social learning as the foundations of management learning, education and learning for social matter.

\section{MATERIALS AND METHODS}

Management education and social learning: The globalization of business, the technological revolution as well as the requirements of the knowledge society in the 21 st century are all expect for a renewal in management education of future leaders in business school. Theoretically, one may consider that management education operated in environments characterized by volatile change with high complexity which not complete, if firm ignorance social setting. While most management education focus more on management of knowledge to improve performance and to innovation, particularly on how well firms can motivate workforce to achieve organizational goal, rather than create a better life for others.

Management education literature has long considered both on education role and economics return under university platform (Petriglieri and Petriglieri, 2010; Pfeffer and Fong, 2004). Consequentially, the purpose of business school is clearly to access its relevance by the responses it gets from the market that is why the dean need to being both highly responsive to the market and alert to possibilities to lead the market. Lorange (2002) stated that "a market perspective should always prevail"). Which lead to the implication for faculty members is that "a professor must be billable in order to justify his presence on the academic team"). Billable defined as a faculty member must be in demand by client firms and executives (Lorange, 2002). Furthermore, one may believe that "business schools need to broaden the term "student to client"). In sum, it seems clear that management education philosophy exemplify that management education should prevail on keeping business school relevant on emphasizing increase market orientation, rather than being fundamentally disciplinary and axiomatic. Critical questions that need an absolute answer is how adequate that business school are training graduate into turbulent business environment (Bennis and O'Toole, 2005; Dyer et al., 2011). Particularly when Bennis and O' Toole (2005) quoted that "Business school are on the wrong track).
Leading by Harvard Business School that was delivered entrepreneurship course in 1947, Entrepreneurship Education (EE) programs in higher education have grown rapidly and globally. On the other hand, few curriculum has focused on social entrepreneurship. However, the alignment of business and management priorities and values with commitment to community and social aims can be pragmatically and ideologically conflict ridden. Recent research exhibited the tension between social and business values has the potential to create huge opportunities for many management education program, particularly leadership development program. It all account for the development of the "state of art" in management education that concern today problems as future renewal perspective for better tomorrow. Creating sustainable societies has become a central tenet of business and economic development such as an essential result in $17 \mathrm{UN}$ sustainable development goals.

\section{RESULTS AND DISCUSSION}

Shifting management education to social learning on enhancing social entrepreneurship: Although, evidence shows that management education represents the most active and substantial influence on business leadership development, understanding of the process of how to develop the preference business logic is still limited. This study draw an attention on shifting management education, the action learning process and the role of recognizing the value of social learning action on the supervision on transformational leader to embed graduate education to enhance more on social learning. This new challenge put a priority on shifting a design of management education through "social learning" deployed through an effective curriculum that encourage young leader to be able to perceive the value of social capital on three dimensions of intellectual capital.

Social theories of learning are insightful in this process particularly their association with identity which raises interesting tensions for social entrepreneurship. Previous empirical research has shown that social entrepreneurs are most often driven by social values and more likely to couch their identities in terms of their roles in community that in management or entrepreneurial term (Parkinson and Howorth, 2008). Therefore, considering learning within the context of social entrepreneurs can lead management education to achieve their social aims. Because social entrepreneurs need to act entrepreneurially in identifying and exploiting market opportunities and they will use business skills to ensure that their venture is sustainable. 
Social theories of learning approach contrasts with traditional cognitive theory that dominates the thinking on learning and practice of education. Cognitivist approach views the learner as being able to consume abstract knowledge which Freire refers to as the "banking concept" of education because teachers transfer knowledge to students. Social learning are fundamentally different because they are interested in what kinds of social engagement provide the best context for learning to take place (Hanks, 1991). Social learning preferred learner to identify social problems that may lead to opportunities (Gherardi et al., 1998). Therefore, social learning shifts attention form the processing of information to processes of participation and interaction that provide and sustain the real context to learning (Gherardi et al., 1998). The focus, thus, shifts management education from individual as learner to learning as participation in a social world to be the one which involves a community highlights an implication for social entrepreneurship.

Management education in developing social economy toward social entrepreneurship: With the emergence of initiatives such as the UN Global Compact and the Principles for Responsible Management Education which encourage the development and dissemination of socially responsible business practices and enlightened management education. Therefore, many educators grasp with the means by which learners at all levels and circumstance introduced to the multifaceted issues involved and develop the skills necessary to be competent in social fixing practices. The social economy refers to the third sector in economies between the profit-oriented private sector on one hand and the public sector on the other. These organizations are hugely diverse in terms of their "age, size, legal status, strategies and missions, funding arrangements, level of profit orientation, ownership and relationship with communities" (Di Domenico et al., 2009a). Because such organizations share a common goal which is to pursue social objectives and their engagement with society. It demanding management education to perfectly intervene in order to provide business graduate that be able to seeks to reflect the needs of local people to identify the services required in their communities and to tailor their provision to meet demand (Di Domenico et al., 2009a).

Enhancing social economy through social entrepreneurship program has received increased attention in the literature and is being increasing recognized by both researchers and policy makers for the potential influences it can bring benefits to the local communities, including the provision of goods, services and social benefits that would be generate the prosperity by fixing the market failure (Kneiding and Tracey, 2009), job creation (Doherty et al., 2009) as well as the promotion of corporate social responsibilities agenda within commercial corporations (Tracey et al., 2005; Di Domenico et al., 2009b). Shared understandings among management education concerning social economy can be seen consistently with the increasing widely held belief that universities have a moral obligation to produce not only innovation and entrepreneurial graduates (Thompson et al., 2010, 2012) but also civically aware and socially responsible citizens (McDonald and Donleavy, 1995; Steiner and Watson, 2006).

The rise of management education on social economy programs has grown steadily in developed countries in the past two decades (O'Neill, 2005; Mirabella et al., 2007). While social economy has grown to 426 of such programs offered by 238 US institution (Mirabella, 2007) by 2006 . However, some of these programs have received heavy criticism (McDonald and Donleavy, 1995). It is because of using traditional teaching approaches. Encouraged by social learning theories (Hanks, 1991; Gherardi, 1995; Gherardi et al., 1998), educators have also shifted to more interactive methods of teaching, particularly those used commonly in business and management courses to achieve the distinctive challenges for the development of social entrepreneurship at core value of core ideology (MacDonald, 2012; Parkinson and Howorth, 2008).

Turning intellectual capital toward social entrepreneurship through management education: As the business environment has become more complex and uncertain, organizations have responded by increasingly using innovation as their fundamental strategy in an effort to be more competitive. Organizational researchers have begun to create increasingly comprehensive models of innovation development. Recent advances in organizational capability widely accepted that innovation is closely tied to intellectual capital and its ability to utilize its knowledge resources. Several studies designating an organization's knowledge resources as its intellectual capital. Subramaniam and Youndt considered that intellectual capital to be the sum of all knowledge firms utilize for competitive advantage (Nahapiet and Ghoshal, 1998). Previous research in organizational literature, on the other hand has identified three prominent aspects of intellectual capital, social, organizational and human capital. Therefore, transforming intellectual capital to social entrepreneurship need to address this keys factors successfully. 
Transforming intellectual capital toward social entrepreneurship through social identity and selfefficacy approach: Social capital is defined as the knowledge embedded within, available through and utilized by interactions among individuals and their networks of interrelationship (Nahapiet and Ghoshal, 1998). Coleman (1990) defined social capital as any aspect of social structure that create value and facilitates the actions of individuals within that social structure. Just as the creation of physical capital involves changes in materials, so as to facilitate management learning and human capital involves changes in an individual's skills and capabilities. In sum, social capital is created when the relations among people change in way that facilitate instrumental action (Coleman, 1990). Therefore, raising awareness of social entrepreneurship on social capital platform is recommended, particularly, throughout the business school community and thus, encourage faculty from all disciplines to consider incorporating some of the ideas in to their teaching is encouraged.

Core purpose is to create teaching relevant concepts, strategies and theories, social entrepreneurship education that provide the opportunity to develop social entrepreneurs by given the students opportunity to develop social entrepreneurs and learn to see themselves as capable social innovators (Smith and Woodworth, 2012). Simply created, the management education objective is to empower student with vision to how they can take initiative to address real societal problems through social identity and self-efficacy approach. To foster social entrepreneurship, management education should base that course content can be a catalyst that channels and enhances student's desires to make a difference in the world helping them identify with the social entrepreneurship community and develop beliefs that they have tools, abilities and resources necessary to begin making a contribution (Smith and Woodworth, 2012). The goal is to have students leave the course with self-views that are reflected in the statement such as, "I want to help tackle the world 's social ills because that is who I am I can be a social entrepreneur" and "I am confident that I truly can make a differences in the world and I can begin right now (Smith and Woodworth, 2012).

According to social identity theory (Tajfel and Turner, 1979), people form social identities based on a sense of belonging to a certain social category (e.g., nationality, organization, social entrepreneurs, ect.). The social category becomes self-definitional, influencing a person's self-concept as well as behavior-in terms of that category: people have repertoire of such discrete category memberships that vary in relative overall importance in the self-concept. Each of these memberships is represented in the individual member's mind as social identity that both describes and prescribes one's attributes as a member of that group-that is what one should think and feel and how one should behave (Hogg et al., 1995). Explain by self-categorization theory (Turner et al., 1987) in which people create social identity when individuals depersonalize their self-concept and cognitively assimilate their own identity into that of an in group prototype. An individual's social identity is thus largely based on a sense of shared destiny or fate and a joint stake in future successes and failures (Mael and Ashforth, 1992). Turning intellectual capital through an identity approach to social entrepreneurship, therefore, encourages management education as social category in which graduates become active members to find an opportunity and to begin identifying with innovators and social entrepreneurs and consequently, develop desires to make a positive contribution to society on oneself self-efficacy on social identity basis.

\section{Management education of enhancing self-efficacy toward social entrepreneurship: Self-efficacy describes} "people's beliefs in their capabilities to mobilize the motivation, cognitive resources and course of action needed to exercise control over events in their lives" (Wood and Bandura, 1989). Educating individual with high social entrepreneurial self-efficacy-that is a belief in one's ability to effect positive social change-will thus be more likely to engage, persist and perform well in efforts that help creating social value. The strategy to develop self-efficacy in the domain of social entrepreneurship rest on the education of social entrepreneurs.

To address effectively, Wood and Bandura (1989) proposed prominent three processes to promote management learning relevant to social entrepreneurship education by which an individual's self-efficacy in influenced: personal mastery experiences (i.e., personal success in past performance), modeling (i.e., vicarious learning by observing others), social persuasion (i.e., realistic encouragement). Elevating formal education in the university setting can be and effective means of harnessing such processes to positively influence student's perceptions of self-efficacy toward social entrepreneurship (Wilson et al., 2007). Moreover, exposure to entrepreneurial role models has also been shown to increase entrepreneurial self-efficacy (BarNir et al., 2011). As a result, management education will be more likely to actually transform intellectual capital toward social entrepreneurship behavior. 


\section{CONCLUSION}

Today, management education faces intense criticism for failing to impart useful skills and failing to prepare leaders who can lead change effectively with their moral reasoning and ethical behavior (Benis and O'Toole, 2005). The challenge is emphasis on how management education can teach and energize knowledge, skills and embedded desired attitude of the future leaders to act successfully to solve social illness through social entrepreneurship. Although, social entrepreneurship education programs have arisen in university curricula worldwide (Brock, 2008). This growth is driven by several factors including an increased demand by social entrepreneurs seeking business skills on top of intellectual capital on social issues within and outside organizations.

Furthermore, there is growing demand for management education to take a stronger role in providing students with social foundations and it implication toward sustainability. This study is an attempt to increase attention paid to intellectual capital which embedded within organizations and societies as well. However, social entrepreneurship discipline still continues to be plagued by the complexity of its dual mission and by the lack of consensus on the concepts, competencies and types of skill development that students need. Therefore, identifying these key debates and issues of management education is crucial. Particularly in today situation, management education requires a critical assessment of the role of management teaching and learning process. Introducing alternative mode of learning may offer the better solution on practical implication for preparing young leader with good desired behavior with good desired business logic as well as equip them with knowledge for their lifetime continuous improvement.

\section{REFERENCES}

BarNir, A., W.E. Watson and H.M. Hutchins, 2011. Mediation and moderated mediation in the relationship among role models, self-efficacy, entrepreneurial career intention and gender. J. Appl. Soc. Psychol., 41: 270-297.

Bennis, W.G. and J. O'Toole, 2005. How business schools lost their way. Harv. Bus. Rev., 83: 96-104.

Brock, D.D., 2008. Social entrepreneurship teaching resources handbook. Master Thesis, Ashoka Global Academy, Nashik, India.

Coleman, J., 1990. Foundation of Social Theory. Harvard University Press, Boston, Massachusetts,
Di Domenico, M., P. Tracey and H. Haugh, 2009b. Social economy involvement in public service delivery: Community engagement and accountability. Reg. Stud., 43: 981-992.

Di Domenico, M., P. Tracey and H. Haugh, 2009a. The dialectic of social exchange: Theorizing corporate-social enterprise collaboration. Organ. Stud., 30: 887-907.

Doherty, B., G. Foster, C. Mason, J. Meehan and $\mathrm{K}$. Meehan et al., 2009. Management for Social Enterprise. SAGE Publications, Thousand Oaks, California, USA., ISBN:9781412947480, Pages: 240.

Dyer, J., H. Gregersen and C.M. Christensen, 2011. The Innovators DNA: Mastering the Five Skills of Disruptive Innovators. Harvard Business Press, Boston, Massachusetts, ISBN:978-1-4221-3481-8, Pages: 296.

Gherardi, S., 1995. Organizational Learning. In: International Encyclopedia of Business and Management, Warner, H. (Eds.). Routledge \& Kegan Paul Publisher, London, UK., pp: 3934-3942.

Gherardi, S., D. Nicolini and F. Odella, 1998. Toward a social understanding of how people learn in organizations: The notion of situated curriculum. Manage. Learn., 29: 273-297.

Gosling, J. and H. Mintzberg, 2006. Management education as if both matter. Manage. Learn., 37: 419-428.

Hanks, W.F., 1991. Foreword. In: Situated Learning: Legitimate Peripheral Participation, Lave, J. and E. Wenger (Eds.). Cambridge University Press, Cambridge, UK., ISBN:0-521-42374-0, pp: 13-24.

Hogg, M.A., D.J. Terry and M.W. Katherine, 1995. A tale of two theories: A critical comparison of identity theory with social identity theory. Soc. Psychol. Q., 58: 255-269.

Kneiding, C. and P. Tracey, 2009. Towards a performance measurement framework for community development finance institutions in the UK. J. Bus. Ethics, 86: 327-345.

Lorange, P., 2002. New Vision for Management Education: Leadership Challenges. Emerald Group Publishing, Bingley, England, ISBN:9780080440347, Pages: 384.

MacDonald, M., 2012. Charitable enterprise: An investigation of the adoption of social enterprise models of practice by a UK charity. Ph.D Thesis, Lancaster University, Lancashire, England.

Mael, F. and B.E. Ashforth, 1992. Alumni and their alma mater: A partial test of the reformulated model of organizational identification. J. Oraganiz. Bahav., 13: 103-123. 
McDonald, G.M. and G.D. Donleavy, 1995. Objections to the teaching of business ethics. J. Bus. Ethics, 14: 839-853.

Mintzberg, H., 2009. Americas monumental failure of management. The globe and Mail, Toronto, Canada. https://webcache googleusercontent.com/search?q =cache:mpBmzUM26B4J:https://www.theglobeand mail.com/opinion/americas-monumental-failure-ofmanagement $/$ article $783560 /+\& c d=1 \& h l=$ en\&ct $=$ clnk $\& g l=p k \& c l i e n t=$ firefox $-\mathrm{b}$

Mirabella, R.M., 2007. University-based educational programs in nonprofit management and philanthropic studies: A 10-year review and projections of future trends. Nonprofit Voluntary Sect. Q., 36: 11S-27S.

Mirabella, R.M., G. Gemelli, M.J. Malcolm and G. Berger, 2007. Nonprofit and philanthropic studies: International overview of the field in Africa, Canada, Latin America, Asia, the Pacific and Europe. Nonprofit Voluntary Sect. Q., 36: 110S-135S.

Nahapiet, J. and S. Ghoshal, 1998. Social capital, intellectual capital, and the organizational advantage. Acad. Manage. Rev., 23: 242-266.

O'Neill, M., 2005. Developmental contexts of nonprofit management education. Nonprofit Manage. Leadersh., 16: 5-17.

O'Toole, J., 2009. The Pluralistics Future of Management Education. In: The SAGE Handbook of Management Learning, Education and Development, Armstrong, S.J. and C.V. Fukami (Eds.). SAGE Pubications, London, UK., ISBN:978-1-4129-3539-5, pp: 547-558.

Parkinson, C. and C. Howorth, 2008. The language of social entrepreneurs. Entrepreneurship Reg. Dev., 20: 285-309.

Petriglieri, G. and J.L. Petriglieri, 2010. Identity workspaces: The case of business schools. Acad. Manage. Learn. Educ., 9: 44-60.

Pfeffer, J. and C.T. Fong, 2004. The end of business schools? Less success than meets the eye. Acad. Manage. Learn. Educ., 1: 78-95.
Schultz, T.W., 1971. Investment in Human Capital. The Free Press, New York.

Smith, I.H. and W.P. Woodworth, 2012. Developing social entrepreneurs and social innovators: A social identity and self-efficacy approach. Acad. Manage. Learn. Educ., 11: 390-407.

Steiner, S.D. and M.A. Watson, 2006. The service learning component in business education: The values linkage void. Acad. Manage. Learn. Educ., 5: 422-434.

Tajfel, H. and J.C. Tuner, 1979. An Integrative Theory of Intergroup Conflict. In: The Social Psychology of Intergroup Relations, Austin, W.G. and S. Worchel, (Eds.). Brooks/Cole Publishing Company, Monterey, California, ISBN:9780818502781, pp: 33-47.

Thompson, P., C. Kwong and D. Jones-Evans, 2012. Enterprise Education and the Adoption of Newer Technologies within Small Firms. In: New Technology based Firms in New Millennium, Oakey, R., A. Groen, P. Van Der Sijde and G. Cook (Eds.). Emerald Group Publishing, Bingley, UK., pp: 5-22.

Thompson, P., D. Jones-Evans and C.C.Y. Kwong, 2010. Education and entrepreneurial activity: A comparison of White and South Asian Men. Intl. Small Bus. J., 28: 147-162.

Tracey, P., N. Phillips and H. Haugh, 2005. Beyond philanthropy: Community enterprise as a basis for corporate citizenship. J. Bus. Ethics, 58: 327-344.

Turner, J.C., M.A. Hogg, P.J. Oakes, S.D. Reicher and M.S. Wetherell, 1987. Rediscovering the Social Group: A Self-Categorization Theory. Blackwell Publication, Oxford, ISBN: 9780631148067 , Pages: 239.

Wilson, F., J. Kickul and D. Marlino, 2007. Gender, entrepreneurial self-efficacy and entrepreneurial career intentions: Implications for entrepreneurship education. Entrepreneursh. Theor. Pract., 31: 387-401.

Wood, R. and A. Bandura, 1989. Social cognitive theory of organizational management. Acad. Manage. Rev., 14: $361-384$. 